\title{
Laws and Religion: Unravelling McFarlane v Relate Avon Limited
}

\author{
RUSSELL SANDBERG ${ }^{1}$ \\ Lecturer, Cardiff Law School \\ Research Associate, Centre for Law and Religion, Cardiff University
}

The Labour Government (1997-2010) created a large number of new laws affecting religion. The Blair and Brown years saw the incorporation of Article 9 of the European Convention on Human Rights into domestic law, the creation of religiously-aggravated offences, the recognition of civil partnerships, and a tide of legislation affecting education, charities and equality law, which saw the extension of the law to cover discrimination on grounds of religion or belief. And all this legislation has resulted in an abundance of case law. ${ }^{2}$ There is more 'religion law' - national and international law affecting religion than ever before. ${ }^{3}$ And, for some time, there has been an implicit tension in English law between this new religion law and older laws protecting religion. These old laws, many still on the statute books, were based upon a different premise. They often sought to protect Christianity in general (or the Church of England in particular) as the norm, while providing some degree of toleration for other faiths. Moreover, the legal regulation of religion was characterised by a lightness of touch. The new religion law, by contrast, is facilitative, ${ }^{4}$ seeking to protect religious freedom mainly as an individual right which needs to be balanced against other rights. ${ }^{5}$ No special protection is afforded to any one religion and protection is often afforded to non-religious beliefs. The new legal framework affords utmost importance to the concept of religious neutrality as the State takes on the role of facilitating the religious market place. ${ }^{6}$ The tension between the old laws on religion and the new 'religion law' can be seen, for example, in the abolition of the offence of blasphemy (which favoured the

1 I am grateful to my colleagues at the Centre for Law and Religion, especially Professor Norman Doe and Frank Cranmer for their invaluable guidance.

2 See the Law and Religion Scholars Network Case Database at: <http://www.law.cf.ac.uk/clr/networks/lrsncd.html>, accessed 23 July 2010.

3 For further elucidation of the concept of 'religion law' see R Sandberg, 'Church-State Relations in Europe: From Legal Models to an Interdisciplinary Approach' (2008) 1(3) Journal of Religion in Europe 329, 336-340. The concept will be developed in R Sandberg, Law and Religion (Cambridge, 2011) forthcoming.

4 See M Hill and R Sandberg, 'Is Nothing Sacred? Clashing Symbols in a Secular World' [2007] Public Law 488-506.

5 Often, however, individual religious rights are only protected where the beliefs are shared by a group: see Eweida v British Airways [2010] EWCA Civ 80.

6 See, eg the judgment of the Grand Chamber in Refah Partisi v Turkey (2003) 37 EHRR 1 at para 91. 
Church of England in particular) and its replacement by offences concerning religious hatred (which covers all religions). ${ }^{7}$ This tension has recently come to the fore in the Court of Appeal ruling in the application for leave to appeal in McFarlane $v$ Relate Avon Limited. ${ }^{8}$

\section{THE DECISION}

The case concerned a Christian counsellor who was dismissed because he refused to counsel same-sex couples on sexual matters. Both the Employment Tribunal and the Employment Appeal Tribunal (EAT) ${ }^{9}$ rejected McFarlane's claims of unfair dismissal and religious discrimination. The case was almost simultaneous with the factually similar case of Ladele $v$ London Borough of Islington ${ }^{10}$ and so it was unsurprising that the various judgments in McFarlane relied heavily upon those in Ladele, making the dismissal of McFarlane's appeal application almost inevitable. However, McFarlane should not be relegated to footnote status. A witness statement by Lord Carey of Clifton, formerly Archbishop of Canterbury, provoked Lord Justice Laws to deliver a significant judgment which elucidated the relationship between Christianity and the law and, consequentially, the relationship between the older laws on religion and the new religion law.

The Court of Appeal decision focused on the question of indirect discrimination. In relation to direct discrimination, the claim failed because Relate did not treat McFarlane less favourably on grounds of religion. ${ }^{11}$ McFarlane was treated as he was because of his unwillingness to provide counselling rather than because of his Christian faith. The question of indirect discrimination, however, was more controversial. It was agreed that McFarlane had been disadvantaged and that Relate's actions had had a legitimate aim (the provision of counselling services to all sections of the community regardless of sexual orientation) but it was disputed whether the absolute rule was proportionate with McFarlane contending that there was no good reason why he should not be allowed to counsel only heterosexual couples on the basis of his religious convictions about homosexuality. ${ }^{12}$

Both the EAT and the Court of Appeal found Ladele to be definitive on this point. As Laws LJ noted, the two cases 'cannot sensibly be distinguished.' ${ }^{13}$

7 See M Hill and R Sandberg, 'Blasphemy and Human Rights: An English Experience in a European Context' IV (2009) Derecho y Religión [Law and Religion] 145-160.

8 McFarlane v Relate Avon Limited; Application for Leave to Appeal, case number A2/2009/2733.

9 [2009] UKEAT 0106/09/3011 (30 November 2009).

10 Ladele v London Borough of Islington [2008] UKEAT 0453/08/RN (10 December 2008); [2009] EWCA (Civ) 1357. For a fuller discussion of this decision, see Lucy Vickers' article in this issue of the Journal, 'Religious Discrimination in the Workplace: An Emerging Hierarchy?' (2010) 12 Ecc LJ 280-303.

11 Employment Equality (Religion or Belief) Regulations 2003, SI 2003/1660, reg 3(1)(a).

12 Laws LJ noted that, "The applicant is a Christian who (in the words of the EAT, paragraph 4) "believes that it follows from Biblical teaching that same sex sexual activity is sinful and that he should do nothing which endorses such activity": McFarlane v Relate Avon Ltd [2010] EWCA Civ B1 (29 April 2010) at para 4. 
In Ladele ${ }^{14}$ the Court of Appeal emphasised that Ladele was employed in a public job and was being 'required to perform a purely secular task, which was being treated as part of her job'. ${ }^{15}$ The Court of Appeal quoted the EAT's statement that 'the only way in which they could have achieved that aim was by requiring all their registrars to conduct civil partnerships'. ${ }^{16}$ The Court of Appeal held that the aim of their equality policy was 'of general, indeed overarching, policy significance to Islington, and it also had fundamental human rights, equality and diversity implications, whereas the effect on Ms Ladele of implementing the policy did not impinge on her religious beliefs: she remained free to hold those beliefs, and free to worship as she wished'. ${ }^{17}$

There are a number of flaws with this argument in Ladele. The argument seems one-sided. There is no recognition that equality policy protects discrimination on grounds of religion as well as on grounds of sexual orientation. Preventing discrimination on grounds of sexual orientation is described as being of 'overarching, policy significance' whilst freedom of religion is defined very narrowly. Indeed, taken literally, Ladele seemed to suggest that freedom of thought, conscience and religion only included the right to hold beliefs and worship. This is not the case as the text of Article 9 makes clear. In sum, in Ladele the laudable aim of preventing discrimination on grounds of sexual orientation was used to annihilate the claim of religious discrimination. ${ }^{18}$

\section{THE ARGUMENTS}

It is not surprising that counsel for McFarlane chose to focus upon this point in the application for permission to appeal. It was argued that the Court of Appeal judgment in Ladele 'failed properly to consider other decisions' concerning Article 9, ignored the principle of legality and was 'unconstitutional and contrary to the rule of law'. ${ }^{19}$ It was submitted that both the EAT in McFarlane and the Court of Appeal in Ladele failed 'to conduct the balancing exercise' between the two competing claims of religious discrimination and sexual

[2009] EWCA (Civ) 1357.

Para 52.

Para 50.

Para 51.

See further R Sandberg, 'The Implications of the Court of Appeal Decision in Ladele', paper presented to the Interfaith Legal Advisers Network (Lambeth Palace, 1 March 2010), available as part of the Working Paper Series coordinated by the Centre for Law for Law and Religion at Cardiff University. See: <http://www.law.cf.ac.uk/clr/research/WorkingPapers.html>, accessed 23 July 2010.

9 Para 14. McFarlane was not an Article 9 claim. However, under section 3 of the Human Rights Act 1998 , domestic courts are required to construe domestic laws compatibly with Convention rights. As the EAT confirmed in Eweida $v$ British Airways UKEAT/0123/08LA (20 November 2008), this means that 'the same (or at least no less favourable) approach must be adopted to the concept of religion and belief in the 2003 Regulations' as is protected under Article 9: see para 27. 
orientation discrimination. The case was supported by a witness statement by Lord Carey arguing for 'a specially constituted Court of Appeal of five Lords Justices who have a proven sensibility to religious issues' ${ }^{20}$ Lord Carey criticised the description of Christian beliefs about sexuality as 'discriminatory' and lamented what he perceived to be 'disparaging comments' made by senior members of the judiciary which suggested that someone who held religious views was 'a homophobe and disreputable'. He further suggested that the fact that senior clerics felt compelled to intervene in recent cases was 'illuminative of a future civil unrest'.

Laws LJ's judgment sought to address these concerns and focussed mainly upon Lord Carey's statement. He held that this was appropriate given Carey's 'seniority in the Church and the extent to which others may agree with his views, and because of the misunderstanding of the law which his statement reveals'. ${ }^{21}$ The following will seek to elucidate the four key issues discussed in the judgment, namely: the level of protection provided by Article 9, the concept of discrimination, the legal favouring of Christianity and the protection of religious doctrine.

\section{THE PROTECTION PROVIDED BY ARTICLE 9 ECHR}

Laws LJ dealt swiftly with the argument that the judgment in Ladele had been decided per incuriam because it failed properly to consider the Article 9 case law. Counsel for McFarlane contended that the court in Ladele failed to take into account the judgments in Williamson ${ }^{22}$ and Copsey ${ }^{23}$. Laws LJ held that Ladele was not inconsistent with either decision because in both cases it had been held although that the claimant's beliefs fell within the scope of Article 9(1), there had been no breach of Article $9 .{ }^{24}$ However, whilst it is true that the Article 9 claim was unsuccessful in both of these cases, it is also the case that Williamson and Copsey took a more generous approach to Article 9 than subsequent cases. Since the House of Lords decision in Begum, ${ }^{25}$ domestic courts have tended to interpret the Article 9 rights in a narrow and conservative fashion, uncritically following Lord Bingham's questionable assertion that 'interference [with Article 9] is not easily established ${ }^{26}$ and making repeated use of S Langlaude, 'Flogging Children with Religion: A Comment on the House of Lords' Decision in Williamson' (2006) 8 Ecc LJ 339-345.

3 Copsey $v$ WBB Devon Clays Ltd [2005] EWCA Civ 932, discussed by G Watson, 'Sunday Working and Human Rights' (2006) 8 Ecc LJ 333-334. Para 15 .

$R$ (Begum) v Headteacher and Governors of Denbigh High School [2006] UKHL 15.

See para 24 . 
the 'specific situation rule'. ${ }^{27}$ The result of this is that Article 9 is rendered of little practical use. ${ }^{28}$ This tendency could be seen in Ladele. The Court of Appeal held that 'Ladele's proper and genuine desire to have her religious views relating to marriage respected should not be permitted to override Islington's concern to ensure that all its registrars manifest equal respect for the homosexual community as for the heterosexual community'. ${ }^{29}$ The treatment of Article 9 in Ladele was of concern because whilst it highlighted the need to protect discrimination on grounds of sexual orientation, it ignored the need to protect discrimination on grounds of religion or belief. The Court of Appeal decision in Ladele showed how the application of the 'specific situation rule' renders Article 9 impotent by allowing other Convention rights to 'trump' it with ease. It is a matter of regret that Laws LJ did not deal with this matter in McFarlane, ${ }^{30}$ choosing to focus more on refuting the arguments in Lord Carey's witness statement.

\section{THE CONCEPT OF DISCRIMINATION}

Laws LJ held that Lord Carey's concern that Christian views were equated to homophobia was 'misplaced'. ${ }^{11}$ Finding no examples of judges likening Christians to bigots, Laws LJ concluded that Lord Carey's 'mistaken suggestions' arose from a misunderstanding of the meaning attributed by the law to the idea of discrimination. ${ }^{32}$ Laws LJ noted that 'the proposition that if conduct is accepted as discriminatory it thereby falls to be condemned as disreputable or bigoted is a non sequitur.' He noted that the motivation for discrimination could be 'for good or ill' and that was shown by the fact that 'in various contexts the law allows indirect discrimination where (in a carefully controlled legislative

27 This recognises that a person's Article 9 rights may be influenced by the particular situation of the individual claiming that freedom. This principle is not of universal application: it only applies where someone has voluntarily submitted themselves to a system of norms, usually by means of a contract. This voluntary submission creates a 'specific situation' which limits the claimant's right to manifest. Whilst Strasbourg has tended to use this rule only in prescribed circumstances, the domestic judiciary seem to apply it generally. See also James Dingemans' comments on the 'doctrine of non-interference' at pp $371-378$ below.

28 See further, M Hill and R Sandberg, 'Is Nothing Sacred? Clashing Symbols in a Secular World' [2007] Public Law 488-506; R Sandberg, 'The Changing Position of Religious Minorities in English Law: The Legacy of Begum' in R Grillo et al (ed), Legal Practice and Cultural Diversity (Aldershot, 2009) 267-282.

29 [2009] EWCA (Civ) 1357 at para 55.

30 This is especially true in relation to Ladele where it is questionable whether the 'specific situation rule' ought to apply. Ladele had not voluntarily agreed to a contract of employment that included civil partnerships. When Ladele applied for her job, there was no such thing. In Copsey $v$ WBB Devon Clays Ltd [2005] EWCA Civ 932, Rix LJ argued that the specific situation rule did not apply where an employer rather than the employees ought to vary the employee's working hours: see particularly paras $65-67$.

31 Para 18.

32 Para 19. 
setting) it can be shown to have justifiable effects'. These comments are sound. However, they point to a problem with the use of the word 'discrimination' which has been commented upon by David Harte. ${ }^{33}$ For Harte, the word 'discrimination' has 'become a negative concept, expressing prejudiced judgement', and this has occurred to such an extent that it is now difficult to use the word 'to mean the drawing of justified distinctions'. ${ }^{34}$ Indeed, the problematic colloquial meaning of the word 'discrimination' is shown by the fact that the product of the work of the Discrimination Law Review was the Equality Act 2010. ${ }^{35}$ Laws LJ's comments are therefore to be welcomed as an attempt to remove the unintended stigma which has become attached to the word 'discrimination', which may be in part responsible for the frequently simplistic media accounts of litigation. ${ }^{36}$

\section{THE FAVOURING OF CHRISTIANITY}

In relation to the other points raised by Lord Carey, Laws LJ commented that they were 'formulated at such a level of generality that it is hard to know precisely what Lord Carey' meant. ${ }^{37}$ He surmised Carey's argument to be broadly that 'the courts ought to be more sympathetic to the substance of the Christian beliefs referred to than appears to be the case, and should be readier than they are to uphold and defend them..$^{38}$ Expressed in this way, Laws LJ's rejection of Carey's argument seems sound. Human rights and discrimination law safeguards mean that Christianity cannot be singled out for special treatment. However, it is again important not to ignore the other side of the coin. Christianity should not be disadvantaged under the law. The laudable practice of protecting minority faiths should not result in disfavour being shown to Christianity.

Laws LJ addressed this by stressing that:

The general law may of course protect a particular social or moral position which is espoused by Christianity, not because of its religious imprimatur, but on the footing that in reason its merits commend themselves. So it is with core provisions of the criminal law: the prohibition of violence and dishonesty. The Judaeo-Christian tradition, stretching over many centuries, has no doubt exerted a profound influence upon the judgment of

33 D Harte, 'Structures of Religious Pluralism in English Law' in N Doe and R Sandberg (eds), Law and Religion: New Horizons (Leuven, 2010) 159-190.

34 Ibid $164-165$. He proposes the use of the term 'discernment' as an alternative.

35 Emphasis added.

36 See A Bradney, 'Some Sceptical Thoughts about the Academic Analysis of Law and Religion in the United Kingdom' in N Doe and R Sandberg (eds), Law and Religion: New Horizons (Leuven, 2010) 299-314.

37 Para 21.

38 Ibid. 
lawmakers as to the objective merits of this or that social policy. And the liturgy and practice of the established Church are to some extent prescribed by law. But the conferment of any legal protection or preference upon a particular substantive moral position on the ground only that it is espoused by the adherents of a particular faith, however long its tradition, however rich its culture, is deeply unprincipled. ${ }^{39}$

Again, the general underlying point here is sound: we do not live in a theocracy. If Laws LJ is simply asserting that it is not the role of the law to embrace specific examples of religious practice then this is unobjectionable. Laws LJ is correct to maintain that the "precepts of any one religion - any belief system - cannot, by force of their religious origins, sound any louder in the general law than the precepts of any other'. ${ }^{40}$ As he puts it, 'the State, if its people are to be free, has the burdensome duty of thinking for itself'. ${ }^{41}$ However, Laws LJ seems to be stating that the law protects certain values not because they are religious values but by reason of their own merits. This is a different argument from saying that Christian ideas have become submerged into general culture. If Laws Lj's judgment is saying that the law will never protect religion as such then this seems inaccurate. Special treatment is afforded in many areas of law to protect religious ideas. The reason why there is so much religion law is because religious ideas (as opposed to opinions or leisure pastimes) are deemed to be worthy of support. The notion that religion is a good thing and is worth protecting for that reason can still be said to underpin the law. ${ }^{42}$ Laws LJ is correct to say that this does not mean that the State approves of, endorses or follows any particular religious belief. ${ }^{43}$ But the argument that the law will never protect religion as such is questionable. ${ }^{44}$ Indeed, as Laws LJ noted, reflections of a Judaeo-Christian heritage can still be found in English law. Although the ecclesiastical courts have lost their jurisdiction over the enforcement of the law of contract, trusts, defamation and wills, ${ }^{45}$ their legacy upon the substantive laws

39 Para 23.

40 Para 24.

41 Ibid.

42 This has been most clearly elucidated in the context of charity law. See the quotation from Gilmour $v$ Coats [1949] AC 426, HL, at $n 44$ below. In Neville Estates v Madden [1962] Ch 852 it was declared that declared that 'any religion is at least likely to be better than none'.

43 As Patten J held in Varsani v Jesani [2002] 1 P\&CR DG 11, 'the court has no choice but to assume an agnostic role' (para 11).

44 A preferable approach was expressed in Gilmour $v$ Coats [1949] AC 426 concerning charity law: 'The law of England has always shown favour to gifts for religious purposes. It does not now in this matter prefer one religion to another. It assumes that it is good for man to have and to practise a religion but where a particular belief is accepted by one religion and rejected by another the law can neither accept nor reject it. The law must accept the position that it is right that different religions should each be supported irrespective of whether or not all its beliefs are true' (at 458-459).

45 See generally RH Helmholz, The Oxford History of the Laws of England: Volume 1, The Canon Law and Ecclesiastical Jurisdiction from 597 to the 1640s (Oxford, 2004) and RB Outhwaite, The Rise and Fall of the Ecclesiastical Courts, 1500-1860 (Cambridge, 2006). 
and procedures of modern English law continues. Clerical fingerprints can still be found over modern pieces of English law, especially in relation to marriage and education law. ${ }^{46}$ The historical synthesis of law and Christianity means that many laws are the way they are because of those clerical fingerprints. And it is difficult to say that these laws are the way they are simply because their 'merits commend themselves'; especially as the criteria by which we assess such merits itself derive from the same Judaeo-Christian heritage.

Laws LJ's reasoning needs to be understood within the context of the new religion law, which is underpinned by a notion of religious equality that is ahistorical and which does not sit comfortably with legal reality. In modern eyes, many aspects of the UK constitution may appear 'unprincipled' (to use Laws LJ's term) but this does not mean that they are wrong and need to be changed. This is true of the benefits and burdens placed on the Church of England as the established church. As Strasbourg has stated, the existence of a State Church is not in itself incompatible with the European Convention on Human Rights; there is only incompatibility if that special treatment prevents the religious freedom of those who do not conform to the State Church. ${ }^{47}$ It must be remembered that the new religion law and its rhetoric of religious neutrality does not exist in a legal and historical vacuum.

\section{THE PROTECTION OF RELIGIOUS DOCTRINE}

In addressing Lord Carey's concerns, Laws LJ emphasised the 'important distinction ... drawn between the law's protection of the right to hold and express a belief and the law's protection of that belief's substance or content'. ${ }^{4}$ He held that the common law and Article 9 provided 'vigorous protection of the Christian's right (and every other person's right) to hold and express his or her beliefs' but 'do not, and should not, offer any protection whatever of the substance or content of those beliefs on the ground only that they are based on religious precepts. ${ }^{49}$ Again, this is unobjectionable if it is merely an assertion that we do not live in a theocracy. Law LJ's comments are also welcome if they are meant as recognition of religious autonomy, reaffirming Lord Nicholls'

46 For example the Matrimonial Causes Act 1857, s 22, provides that the proceedings and actions of the courts of the State should be 'conformable to the Principles and Rules on which the Ecclesiastical Courts have heretofore acted and given Relief'; the School Standards and Framework Act 1998 requires a daily act of worship in schools which is wholly or mainly of a broadly Christian character' (s 70, sch 20).

47 See Darby v Sweden (1991) 13 EHRR 774 As Ahdar and Leigh point out, legal preference for a certain religion is not antithetical to religious freedom 'at least in its contemporary, milder form: the two can coexist as a matter of principle provided that legal preference is not accompanied by distinct civil and legal disabilities for the non-adherents of the official religion': R Ahdar and I Leigh, Religious Freedom in the Liberal State (Oxford, 2005) 129-30.

48 Para 22.

49 Ibid. 
judgment in Williamson that courts should be reluctant to intervene in doctrinal matters. ${ }^{50}$ While Courts may be concerned with whether or not the claim of religious belief was made in good faith, they are not concerned whether the religious belief professed is a good faith in terms of judging the validity of that faith..$^{11}$ Laws LJ's comments are especially welcome since some of the lower court decisions have increasingly entered into what Laws LJ referred to as the 'belief's substance or content' in order to determine whether the manifestation is obligatory or central to the belief. ${ }^{52}$

However, it is questionable whether a watertight line can and should be drawn between the protection of the right to hold a belief and protection of the content of that belief. Surely it is the substance or content of the belief that singles it out for protection. As Lord Nicholls noted in Williamson, in order to be protected as a manifestation of belief under Article 9, a belief 'must relate to matters more than merely trivial. It must possess an adequate degree of seriousness and importance. [It] must be a belief on a fundamental problem. ... The belief must also be coherent in the sense of being intelligible and capable of being understood'. ${ }^{53}$ The reason why a belief in the supreme nature of the Jedi knights is not protected is precisely because the substance or content of that belief does not meet the Williamson thresholds. ${ }^{54}$

Laws LJ seems to be saying that the substance of beliefs should not be protected solely on the ground that they are 'religious precepts'. Laws LJ's reasoning appears to go too far. This is most notable when he asserts that:

The promulgation of law for the protection of a position held purely on religious grounds cannot therefore be justified. It is irrational, as preferring the subjective over the objective. ${ }^{55}$

A lot depends on the meaning of the word 'purely' here. Arguably Article 9 and several other pieces of religion law have been promulgated in order to provide 'protection of a position held on religious grounds'. This is perhaps epitomised by the numerous exceptions afforded in discrimination law to religious groups. ${ }^{56}$ And the Strasbourg jurisprudence makes it plain that the State is

$50 R v$ Secretary of State for Education and Employment, ex parte Williamson [2005] UKHL 15 at para 33.

51 R Sandberg, 'Controversial Recent Claims to Religious Liberty' (2008) 124 Law Quarterly Review 213.

52 See, for instance, $R$ (on the Application of Playfoot (A Child)) v Millais School Governing Body [2007] EWHC Admin 1698.

53 [2005] UKHL 15 at para 23.

54 This example was raised by the then Attorney General in debates concerning what was to become the Equality Act 2006: see the discussion in Grainger PLC v Nicholson [2009] UKEAT 0219/09/ZT (3 November 2009) at para 28.

55 [2005] UKHL 15 at para 24.

56 See R Sandberg and N Doe, 'Religious Exemptions in Discrimination Law' (2007) 66(2) Cambridge Law Journal 302-312. The impact of recent case law and the Equality Act 2010 in this area will be discussed in R Sandberg, 'The Right to Discriminate' (2011) 13 Ecc LJ (forthcoming). 
obligated to facilitate religious freedom. Although many laws are underpinned by a perception that there is a need to protect religion in its own right, it is unclear whether they were promulgated to protect views held 'purely' on religious grounds. The reference to objectivity and subjectivity is also troubling, bearing in mind Lord Nicholls' statement in Williamson that 'freedom of religion protects the subjective belief of an individual'. ${ }^{57}$

\section{CONCLUSIONS}

It would be unfortunate if the Court of Appeal decision in Ladele were to overshadow the decision in McFarlane. Laws LJ's judgment will have important ramifications upon the future protection of law and religion in the United Kingdom. By following Ladele and by not criticising its reasoning in relation to Article 9, McFarlane endorses a trend whereby more protection is seemingly given to combating discrimination on grounds of sexual orientation than preventing discrimination on grounds of religion or belief. McFarlane gives further weight to the impression that Article 9 becoming increasingly toothless.

However, Laws LJ's flat rejection of Lord Carey's call for a specially constituted Court of Appeal protecting religious issues was undoubtedly the correct response to a proposal which showed a complete lack of understanding of the judicial process. ${ }^{58}$ Lord Carey's call was particularly ironic given that Lord Carey was one of the most vocal critics of his successor's lecture in which Dr Rowan Williams suggested tentatively that more use could be made of religious courts. $^{59}$ The nuance found in Dr William's lecture was clearly absent in Lord Carey's witness statement.

The broad thrust of Laws LJ's judgment in McFarlane is thus to be welcomed, especially his attempt to remove the stigma that surrounds the word 'discrimination' and the re-emphasis that courts should be reluctant to intervene in doctrinal matters. However, there are other aspects of the judgment that are open to different and sometimes worrying interpretations. It may be inferred from the judgment that there is no reason to protect religion as such. McFarlane underscores the shift that has taken place in the protection of religion. English law now has several laws which seek to protect religion as an individual right and great emphasis is given to the notion of religious neutrality. However, these new laws do not exist in a legal and historical vacuum. And existing and seemingly 'unprincipled' laws which do not fit neatly with newer ideas of religious neutrality are not necessarily wrong or incompatible.

doi:10.1017/So956618X10000451

58 See M Hill, 'Judges should not be handpicked', Church Times, 23 April 2010.

59 See R Williams, 'Civil and Religious Law in England - A Religious Perspective' (2008) 10 Ecc LJ 262. 